\title{
An Optical Sensor Based on Immobilized Copper(II) Ions for the Determination of Free Glutamate in Food Samples
}

(Sensor Optik Berdasarkan Pemegunan Ion Kuprum(II) untuk Penentuan Glutamat Bebas dalam Sampel Makanan)

\author{
NoOr Zuhartini Md Muslim*, Musa Ahmad, Lee Yook Heng \& BAHruddin SAAD
}

\begin{abstract}
An optical fiber chemical sensor for the determination of free glutamate in food samples was fabricated based on the immobilization of $0.1 \mathrm{M}$ copper(II) nitrate trihydrate onto sol-gel glass powder which was then mixed with methyl cellulose to form a pellet. A distinctive colour change from light blue to dark blue was observed in the presence of glutamate in less than $1 \mathrm{~min}$. The colour change was measured by reflectance spectrophotometer at $691 \mathrm{~nm}$. A linear relationship between the reflectance intensity and glutamate concentration was observed in the range of 12.5 to $500 \mathrm{mM}$ with a limit of detection of $10.6 \mathrm{mM}$. This method is also reproducible with a relative standard deviation of less than $5 \%$, no effect on pH of the glutamate solution and a good recovery of above $80 \%$. The sensor was used for the determination of glutamate in common food items such as soups and flavor enhancers. The results obtained from the fabricated sensor were found to be comparable with HPLC method.
\end{abstract}

Keywords: Copper(II) nitrate trihydrate; free glutamate; optical fiber chemical sensor; sol-gel glass powder

ABSTRAK

Sensor kimia gentian optik untuk penentuan glutamat bebas dalam sampel makanan telah direka bentuk berdasarkan pemegunan 0.1 M kuprum(II) nitrat trihidrat ke atas serbuk kaca sol-gel yang kemudiannya dicampur dengan metil selulosa untuk dijadikan pelet. Perubahan warna yang ketara daripada biru muda ke biru tua telah diperhatikan dengan kehadiran glutamat kurang daripada satu minit. Perubahan warna ini diukur dengan spektrofotometer pantulan pada $691 \mathrm{~nm}$. Perhubungan linear antara keamatan pantulan dan kepekatan glutamat telah ditunjukkan dalam julat 12.5 ke $500 \mathrm{mM}$ dengan had pengesanan adalah 10.6 mM. Kaedah ini juga boleh dihasilkan semula dengan sisihan piawai relatif kurang daripada 5\% serta tidak memberi kesan kepada pH larutan glutamat dan perolehan semula yang bagus iaitu $80 \%$ ke atas. Sensor ini telah digunakan untuk menentukan glutamat dalam bahan makanan lazim seperti sup dan penyedap rasa. Keputusan yang diperoleh daripada sensor yang direka bentuk didapati boleh banding dengan keputusan yang diperoleh melalui kaedah HPLC.

Kata kunci: Glutamat bebas; kuprum(II) nitrat trihidrat; sensor kimia gentian optik; serbuk kaca sol-gel

\section{INTRODUCTION}

Glutamate is one of the most abundant excitatory neurotransmitters in the central nervous system (Liu et al. 1997). It is implicated in a variety of human disorders, particularly Alzheimer's, Huntington's chorea and amyotrophic lateral sclerosis (Raiten et al. 1995). Monosodium glutamate (MSG) is used as a flavor enhancer in a variety of foods prepared at home, in restaurants and by food processors. Simultaneous symptoms of MSG sensitivity, also known as Chinese Restaurant Syndrome, are burning, tightness and numbness, commencing between $10 \mathrm{~min}$ and $2 \mathrm{~h}$ after the start of a meal and lasting for $4 \mathrm{~h}$ or less (Kerr et al. 1979). Therefore, it is very important to develop a simple, rapid and reliable analytical method for measuring glutamate in foods.

Several methods for the determination of L-glutamate have been described including HPLC (Populin et al. 2007), amperometric biosensor (Batra et al. 2014; Hughes et al.
2015; Jamal et al. 2013; Upadhyay et al. 2006; Yu et al 2015), spectrophotometric biosensor with flow injection analysis (Khampha et al. 2004), fluorometric biosensor (Chapman \& Zhou 1999) and potentiometric biosensor (Batra et al. 2016; Oliveira et al. 2001). Before analysis can be carried out using HPLC with fluorescence detector (Populin et al. 2007), several steps are required, such as sample derivatization, sample dilution, complicated and time-consuming sample preparation procedures which are unsatisfactory for rapid analysis of a large number of samples. On the other hand, enzyme-based biosensors are selective and able to achieve low limits of detection. However, enzymes are often sensitive to $\mathrm{pH}$, temperature (must be stored at $4^{\circ} \mathrm{C}$ if not in use) and have limited shelf-life.

Another approach for the determination of glutamate is by using optical chemical sensor. These sensors are attractive because of their simple handling and low-cost. 
In this report, the development of an optical chemical sensor for detecting free glutamate in food is presented. The principle of the proposed sensor is based on the formation of complex between copper(II) and glutamate. The distinctive, readily observable colour change from light blue to dark blue from different glutamate concentrations can be observed visually or monitored spectrophotometrically. Copper(II) salts are immobilized into sol-gel powder which was then mixed with methyl cellulose to form a pellet.

\section{MATERIALS AND METHODS}

\section{REAGENTS}

Copper(II) nitrate trihydrate was purchased from R\&M Chemicals (Essex, UK). Tetraethyl orthosilicate (TEOS) and methyl cellulose were obtained from Aldrich (Steinheim, Germany). Hydrochloric acid (37\%) and 99.5\% ethanol were obtained from System (Russellville, USA) and monosodium glutamate monohydrate from Across Organic (New Jersey, USA). All chemicals used were of analytical grade and deionized water was used for solution preparation.

A stock $\mathrm{Cu}$ (II) solution (4 M) was prepared by dissolving copper(II) nitrate trihydrate $(241.60 \mathrm{~g})$ in deionized water $(250 \mathrm{~mL})$. A sol-gel solution was prepared by mixing TEOS $(30 \mathrm{~mL}), 0.5 \mathrm{~mL} \mathrm{HCl}(0.1 \mathrm{M})$, ethanol $(31 \mathrm{~mL}, 99.5 \%)$ and deionized water $(30 \mathrm{~mL})$. This solution was then stirred for $2 \mathrm{~h}$ and left for one day in a closed container before use. A stock solution of glutamate $(2 \mathrm{M})$ was prepared by dissolving monosodium glutamate monohydrate $(93.57 \mathrm{~g})$ in deionized water $(250 \mathrm{~mL})$. Working standard solutions of glutamate were prepared by appropriate dilution of the stock solution before use.

\section{SAMPLE PREPARATION}

Three types of food were used as test samples: Liquid, solid and semi-solid. Liquid samples were used directly without dilution. Solid and semi-solid were dissolved in boiling water according to manufacturer's instructions. These samples were then treated as liquid samples.

\section{CONSTRUCTION OF CHEMICAL SENSOR}

A $0.1 \mathrm{M} \mathrm{Cu}$ (II) solution was mixed with sol-gel solution $(15 \mathrm{~mL})$. The mixture was stirred thoroughly and poured into a petri dish (diameter, $10 \mathrm{~cm}$ ). Then, the mixture was left to dry in an oven for $5 \mathrm{~h}$ at $50^{\circ} \mathrm{C}$. The resultant blue transparent glass was ground to small particles whose size was determined by molecular sieves. The optimum particle size $(<90 \mu \mathrm{m})$ was mixed with methyl cellulose in a ratio of $1: 1(\mathrm{w} / \mathrm{w})$. Methyl cellulose was added to ensure that the particles adhered to each other. A small amount of this mixture was pressed in a pellet press (Parr Instrument Company, USA) to form a pellet (diameter, $1.3 \mathrm{~cm})$.

\section{InSTRUMENTATION AND MEASUREMENT PROCEDURE}

All reflectance measurements were carried out using a fiber-optic spectrophotometer (Ocean Optic SD 2000). Glutamate solution was dropped onto the pellet of immobilized reagent. Reflectance measurements were carried out by placing the pellet at the tip of the optical fiber. The change in reflectance signal was recorded. At least three readings were made for each concentration of substrate solution. The measurements were expressed as the relative reflectance, defined as the reflectance of the $\mathrm{Cu}$ (II)-glutamate complex after reaction with substrate minus the reflectance of the immobilized $\mathrm{Cu}(\mathrm{II})$ alone. Both were recorded at the same measurement wavelength (691 nm).

The results from the glutamate chemical sensor were compared with HPLC method. For HPLC method, the sample was appropriately diluted before the measurement was carried out. The HPLC was operated in the isocratic mode. Glutamate was pre-column derivatized with o-phthaldialdehyde (OPA) (Ryth-Rinder et al. 2001). OPA (108 mg) was dissolved in $1 \mathrm{~mL}$ of $99.5 \%$ ethanol and boric acid buffer $(0.4 \mathrm{M}, \mathrm{pH} 10.4)$ was added to a volume of $10 \mathrm{~mL}$. The OPA reagent was activated by adding 20 $\mu \mathrm{L}$ of mercaptoethanol followed by $20 \mu \mathrm{L}$ glutamate for $1 \mathrm{~min}$. The HPLC measurement was carried out using a Jasco PV-1580 HPLC unit fitted with a ThermoHypersilKeystone Hypersil ODS C18 column $(250 \times 4.6$ mm, $5 \mu \mathrm{m})$ at room temperature. The detector used was a Jasco FD1520-Intelligent Fluorescence detector set at $330 \mathrm{~nm}$ for excitation and $455 \mathrm{~nm}$ for emission. $20 \mu \mathrm{L}$ of sample was injected. The mobile phase used was methanol-phosphate buffer (35:65 v/v, pH5.8).

\section{RESULTS AND DISCUSSION}

The sensing principle of the sensor is based on the formation of $\mathrm{Cu}(\mathrm{II})$-glutamate complex when the immobilized copper reacts with glutamate. The formation of the $\mathrm{Cu}$ (II)-glutamate complex as reported earlier is due to a strong chelate binding effect involving both the carboxylate and amine groups to copper ion (Stone et al. 2004). The blue colour formed is directly proportional to the concentration of glutamate. The structure of the proposed $\mathrm{Cu}(\mathrm{II})$-glutamate complex is shown in Figure 1.

A series of experiments were performed in order to characterize and optimize the sensor response (e.g. the

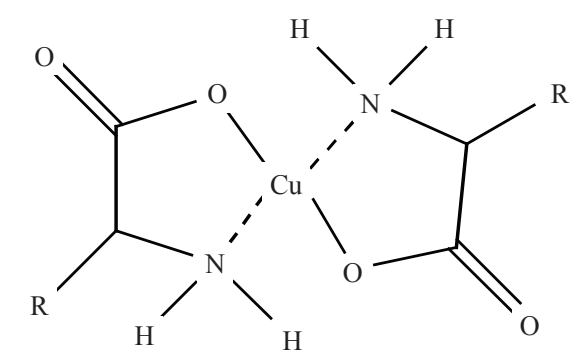

FIGURE 1. Glutamate bond to copper(II) in a chelate-binding mode 


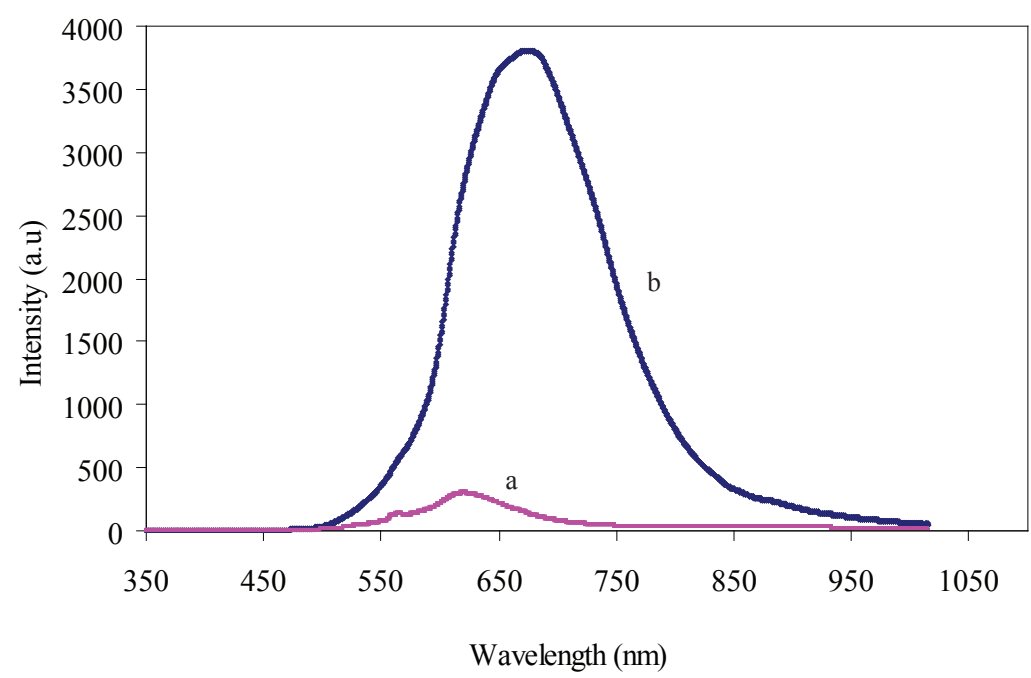

FIGURE 2. Reflectance spectra for immobilized copper (II) ions: (a) before and

(b) after reaction with $2 \mathrm{M}$ glutamate

effects of reagent concentration, particle size and $\mathrm{pH}$ of the glutamate solution), limit of detection, linear range and reproducibility.

Figure 2 shows the reflectance spectrum of the immobilized copper before and after the reaction with glutamate. The formation of the glutamate complex causes a decrease in the reflectance intensity due to the colour change of the reagent phase from light blue to dark blue. The maximum difference of the two reflectance spectra was observed at $691 \mathrm{~nm}$, so this wavelength was used throughout the experiments.

The effect of $\mathrm{Cu}$ (II) concentrations (0.05-0.20 M) on the sensor response was studied. The highest intensity different was observed at $0.10 \mathrm{M} \mathrm{Cu}$ (II) (Figure 3). The light blue colour of $\mathrm{Cu}$ (II) became darker as the concentration of $\mathrm{Cu}(\mathrm{II})$ is increased. Above $0.1 \mathrm{M} \mathrm{Cu}(\mathrm{II})$, the formation of $\mathrm{Cu}$ (II) glutamate complex also produces a dark coloured complex and as a result, reduces the difference in reflectance signal. Therefore $0.10 \mathrm{M} \mathrm{Cu}$ (II) was chosen as the optimum concentration to be used for subsequent studies.
The effect of particle size $(90-1000 \mu \mathrm{m})$ was also studied. The effects of the sol-gel particle size on the sensor performance are shown in Figure 4. Smaller solgel particles produced bigger differences in reflectance intensity due to the increase in surface area (Jouhannaud et al. 2008). The same concentration of reagent immobilized in sol-gel glass after grinding to a smaller particle size showed a light blue colour compared to the dark blue colour exhibited by reagent samples of bigger particle size. Particle size was also observed to influence the time needed for the formation of the $\mathrm{Cu}(\mathrm{II})$-glutamate complex. Reagent with particle size $<90 \mu \mathrm{m}$ gave the fastest response time (less than $1 \mathrm{~min}$.), whereas reagent of larger particle size needed more time for the substrate solution to absorb into the immobilized reagent (Figure 5). Therefore, particles less than $90 \mu \mathrm{m}$ was chosen for subsequent studies.

The response of the sensor was further optimized by evaluating the effects of the $\mathrm{pH}$ of the glutamate solution. Thus, glutamate solutions $(0.1 \mathrm{M})$ were prepared in appropriate buffer solutions with different $\mathrm{pH}$ values ranging from 2 to 12 . The result shows no significant

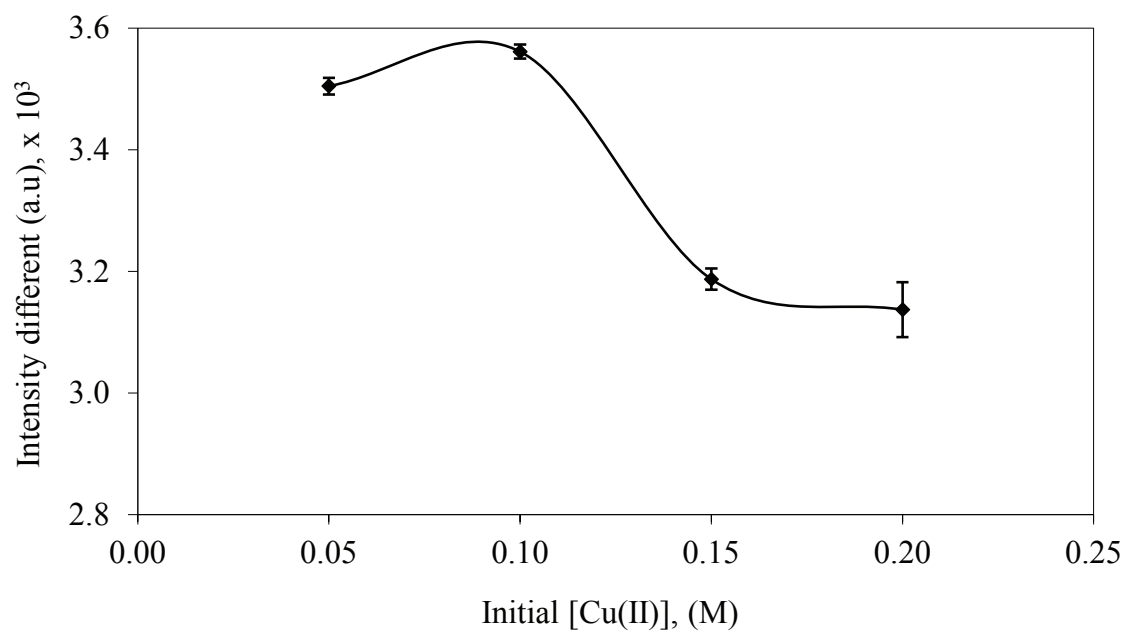

FIGURE 3. Effects of immobilized Cu(II) concentration on glutamate response at $691 \mathrm{~nm}([\mathrm{Glu}]=2 \mathrm{M})$ 


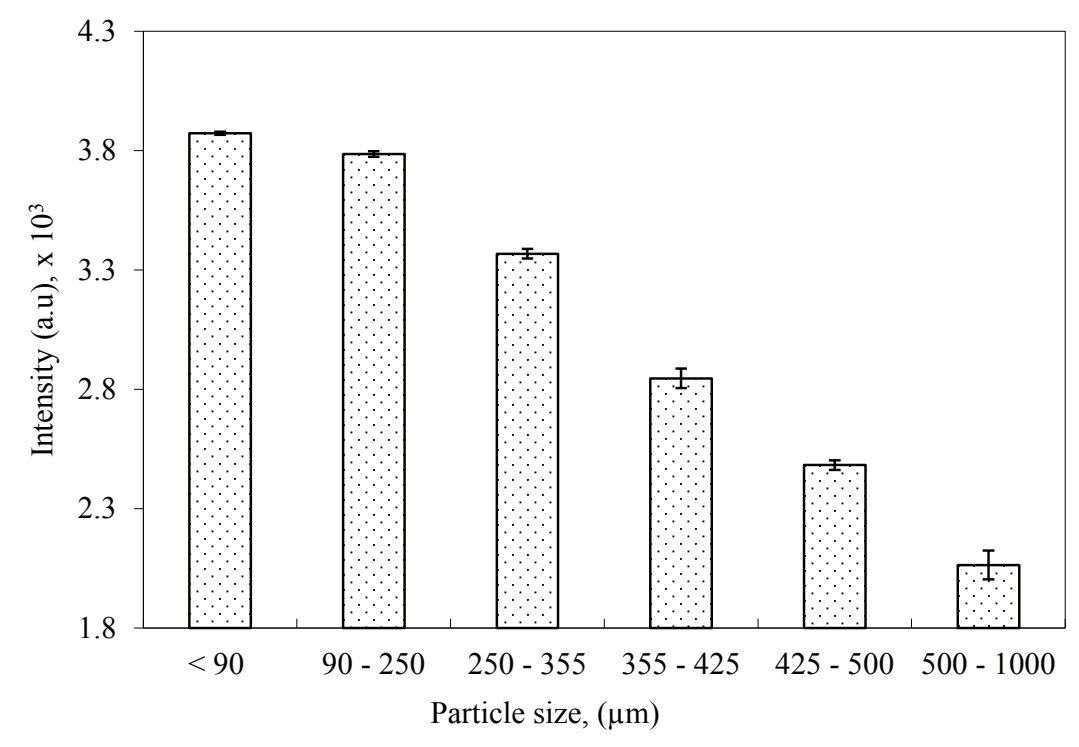

FIGURE 4. Effects of sol-gel particle size on glutamate sensor response at $691 \mathrm{~nm}$

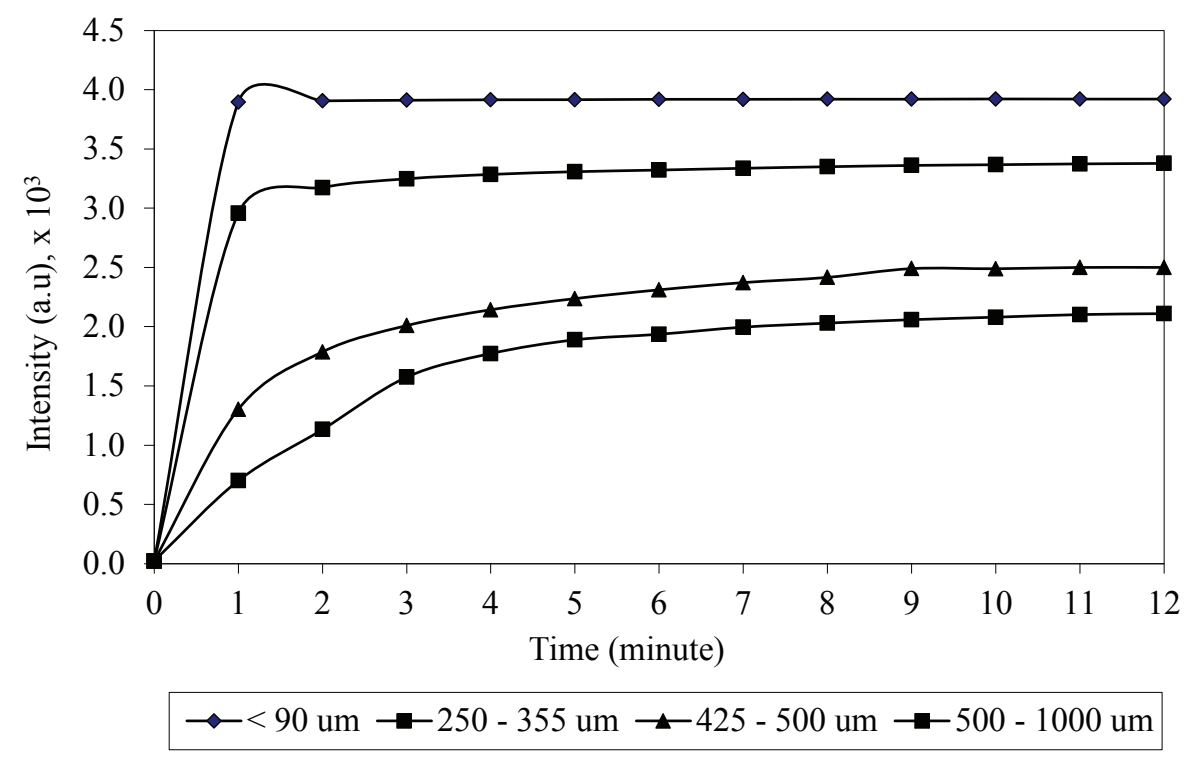

FIGURE 5. Glutamate sensor response at $691 \mathrm{~nm}$ at different size of sol-gel/ $\mathrm{Cu}(\mathrm{II})$

variation of the intensity of the complex as shown by an ANOVA test.

The linear dynamic range was determined by introducing different concentrations of glutamate under optimized conditions. The plot of glutamate concentration against reflectance intensity is linear for glutamate concentrations in the range of 12.5-500 $\mathrm{mM}$ (Figure 6). The limit of detection (LOD) of glutamate, defined here as the concentration equivalent to a signal of blank plus three times the standard deviation of the blank (Miller \& Miller 2000), was calculated to be $10.6 \mathrm{mM}$. This LOD is higher than that of the earlier reported glutamate biosensors, for example, $68 \mu \mathrm{M}$ for the amperometric glutamate biosensor (Jamal et al. 2013); $0.4 \mu \mathrm{M}$ for the flow injection analysis based biosensor (Khampha et al. 2004). Although the sensitivity of the present sensor is inferior to the reported biosensors, it can nevertheless be applied for certain food samples that contain a relatively large amount of glutamate. Glutamate levels range between 6.7 and $658 \mathrm{mg} / 100 \mathrm{~g}$ in fresh food to 0.05 and $6830 \mathrm{mg} / 100 \mathrm{~g}$ in processed food (Janarthanan \& Mottola 1998) have been reported.

Reproducibility study was carried out using a new batch of immobilized reagent after each measurement of the same glutamate concentration. The precision of the sensor performance as reflected in the relative standard deviation when determined from replicate analyses of three different concentrations, namely, $0.025,0.125$ and $0.50 \mathrm{M}$ glutamate, was in the range of $4.2-4.8 \%$.

The interference of other amino acids in the determination of glutamate using the sensor is expected to be insignificant as $\mathrm{Cu}$ (II) will only react with free amino acids. In many processed foods, amino acids are 


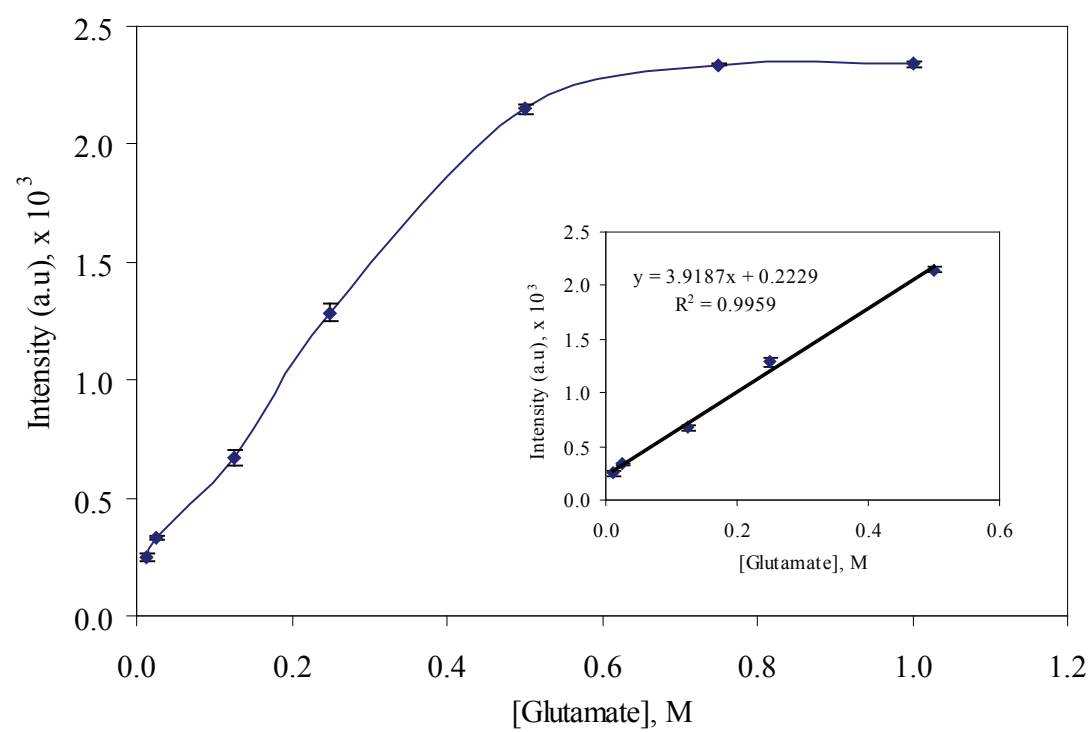

FIGURE 6. Dynamic range of the glutamate sensor response to various concentrations of glutamate determined at $691 \mathrm{~nm}$. The linear range is also shown in the inset

not present in the free form but rather as building blocks in proteins or peptides. Thus naturally occurring amino acids are rarely found in the free form. The effects of other organic acids such as aspartic acid and sorbic acid on the sensor response were studied. Aspartic acid was chosen for the interference study because of the similarity of its structure to that glutamic acid. Both compounds consist of one amino group and two carboxyl groups in their side chain when ionized, are negatively charged and are very polar under physiological conditions (Cozzone 2002). Sorbic acid, on the other hand, was chosen because it is commonly used as a food preservative, especially in fruit jams (Saad et al. 2005) and it contains one carboxyl group, which might have an effect on formation of the complex between the $\mathrm{Cu}$ (II) ion and glutamic acid. In general, it was found that the interference of these acids at low levels is low. However, when present at high concentrations, the interference is quite high (Table 1). The sensor response was found to be unaffected by the presence of common metal ions such as $\mathrm{K}, \mathrm{Na}, \mathrm{Ca}, \mathrm{Mg}$ and $\mathrm{Fe}$.

The effect of the sample matrix was studied by spiking a known quantity of glutamate into three different samples of food, i.e. fried rice seasoning, sour curry paste and concentrated chicken stock. The content of glutamate in the spiked food samples was determined using the glutamate sensor based on measurements of the reflectance intensity. Acceptable results with recovery percentages of $106 \%$,
$84 \%$ and $99 \%$ were obtained for fried rice seasoning, sour curry paste and concentrated chicken stock, respectively (Table 2). The result showed that the matrix in the sample does not interfere with the performance of the glutamate sensor.

Finally, the use of the developed glutamate sensor for real sample analysis was applied to samples of vegetable soup, anchovy stock cube and cream of mushroom soup. The results obtained from the glutamate sensor were compared to the HPLC method (Table 3). A statistical analysis ( $t$-test $)(\mathrm{a}=95 \%)$ carried out by comparing the means of measurements obtained from the two methods showed no significant difference.

TABLE 1. The degree of interference at molar ratio of glutamate: Interference compound

\begin{tabular}{lcc}
\hline Interference compound & $\begin{array}{c}\text { Glutamate: } \\
\text { Interference } \\
\text { compound }\end{array}$ & $\begin{array}{c}\text { Interference } \\
(\%)\end{array}$ \\
\hline Aspartic acid & $1: 1$ & 11 \\
Sorbic acid & $1: 0.2$ & 2 \\
& $1: 0.5$ & 25 \\
& $1: 1$ & 30 \\
\hline
\end{tabular}

Interference $(\%)=((x-y) / y) \times 100$, where $\mathrm{x}$ is the average reflectance value for mixed solution of glutamate and foreign ions, $y$ is the average reflectance value for glutamate solution only

TABLE 2. The results for recoveries of spiked standards to three types of food samples

\begin{tabular}{lcccc}
\hline Sample type & $\begin{array}{c}\text { Amount spiked } \\
(\mathrm{M})\end{array}$ & $\begin{array}{c}\text { Amount before spiking } \\
(\mathrm{M})\end{array}$ & $\begin{array}{c}\text { Amount after spiking } \\
(\mathrm{M})\end{array}$ & Recovery $(\%)$ \\
\hline Fried rice seasoning & 0.25 & 0.116 & 0.380 & 106 \\
Sour curry paste & 0.25 & 0.125 & 0.334 & 84 \\
Concentrated chicken stock & 0.25 & 0.056 & 0.302 & 99 \\
\hline
\end{tabular}

Recovery $(\%)=((x-y) / z) \times 100$, where $\mathrm{x}$ is the average amount of glutamate after spiking, $\mathrm{y}$ is the average amount of glutamate before spiking, and $\mathrm{z}$ is the amount of spiked glutamate 
TABLE 3. Glutamate concentrations in some food samples determined by glutamate sensor and by HPLC

\begin{tabular}{lcccc}
\hline Type of food & Glutamate sensor $(\mathrm{mM})$ & RSD $(\%)$ & HPLC $(\mathrm{mM})$ & RSD $(\%)$ \\
\hline Vegetable soup & $14.8 \pm 0.5$ & 3.1 & $14.5 \pm 0.3$ & 1.8 \\
Anchovy stock cube & $18.4 \pm 0.6$ & 3.3 & $18.1 \pm 0.2$ & 2.8 \\
Cream of mushroom soup & $42.7 \pm 1.6$ & 3.7 & $40.5 \pm 1.5$ & 3.7 \\
\hline
\end{tabular}

\section{CONCLUSION}

An optical glutamate sensor using $\mathrm{Cu}$ (II) immobilized onto sol-gel powder was successfully prepared. The sensor shows good reproducibility (RSD $<5 \%$ ), fast response time (less than $1 \mathrm{~min}$ ) and relatively high limit of detection of $10.6 \mathrm{mM}$. The developed sensor was successfully applied for glutamate determination in real samples and the results obtained were comparable to those obtained with the HPLC method. Compared to the earlier glutamate biosensors that contained delicate enzyme systems, the proposed method is much cheaper, simpler and more robust as it does not depends on the temperature and $\mathrm{pH}$ of the sample. The fabricated sensor is portable (in pellet form) and it requires just a few drops of the samples to get the results instantly.

\section{ACKNOWLEDGEMENTS}

The authors are grateful to School of Chemical Sciences and Food Technology, Faculty of Science \& Technology, Universiti Kebangsaan Malaysia, for providing the facilities used in this research. The author would also like to thank Universiti Sains Malaysia for the financial support under Academic Staff Training Scheme to carry out this research.

\section{REFERENCES}

Batra, B., Kumari, S. \& Pundir, C.S. 2014. Construction of glutamate biosensor based on covalent immobilization of glutamate oxidase on polypyrrole nanoparticles/polyaniline modified gold electrode. Enzyme and Microbial Technology 57: 69-77.

Batra, B., Yadav, M. \& Pundir, C.S. 2016. L-Glutamate biosensor based on 1-glutamate oxidase immobilized onto $\mathrm{ZnO}$ nanorods/polypyrrole modified pencil graphite electrode. Biochemical Engineering Journal 105: 428-436.

Chapman, J. \& Zhou, M. 1999. Microplate-based fluorometric methods for the enzymatic determination of L-glutamate: Application in measuring L-glutamate in food samples. Analytica Chimica Acta 402: 47-52.

Cozzone, A.J. 2002. Proteins: Fundamental Chemical Properties. Encylopedia of Life Science. Lyon, France: Macmillan Publisher Ltd.

Hughes, G., Pemberton, R.M., Fielden, P.R. \& Hart, J.P. 2015. Development of a novel reagentless, screen-printed amperometric biosensor based on glutamate dehydrogenase and $\mathrm{NAD}^{+}$, integrated with multi-walled carbon nanotubes for the determination of glutamate in food and clinical applications. Sensors and Actuators B: Chemical 216: 614-621.

Jamal, M., Hasan, M., Mathewson, A. \& Razeeb, K.M. 2013. Disposable sensor based on enzyme-free Ni nanowire array electrode to detect glutamate. Biosensors and Bioelectronics 40: 213-218.

Janarthanan, C. \& Mottola, H.A. 1998. Enzymatic determinations with rotating bioreactors: Determination of glutamate in food products. Analytica Chimica Acta 369: 147-155.

Jouhannaud, J., Rossignol, J. \& Stuerga, D. 2008. Rapid synthesis of tin (IV) oxide nanoparticles by microwave induced thermohydrolysis. Journal of Solid State Chemistry 181: 1439-1444.

Kerr, G.R., Wu-Lee, M., El-Lozy, M., McGandy, R. \& Stare, F. 1979. Food-symptomatology questionnaires: Risks of demand-bias questions and population-biased surveys. In Glutamic Acid: Advances in Biochemistry and Physiology, edited by Filer, L.J., Garattini, S., Kare, M.R., Reynolds, W.A. \& Wurtman, R.J. New York: Raven Press.

Khampha, W., Yakovleva, J., Isarangkul, D., Wiyakrutta, S., Meevootisom, V. \& Emneus, J. 2004. Specific detection of L-glutamate in food using flow-injection analysis and enzymatic recycling of substrate. Analytica Chimica Acta 518: 127-135.

Liu, M., Rothstein, J.D., Gershon, M.D. \& Kirchgessner, A.L. 1997. Glutamatergic enteric neurons. Journal of Neuroscience 17: 4764-4784.

Miller, J.N. \& Miller, J.C. 2000. Statistic and Chemometrics for Analytical Chemistry. Harlow, UK: Person Education Limited, Prentice Hall.

Oliveira, M.I.P., Pimental, M.C., Montenegro, M.C., Araujo, A.N., Pimentaland, M.F. \& Silva, V.L. 2001. L-Glutamate determination in food samples by flow-injection analysis. Analytica Chimica Acta 44S: 207-213.

Populin, T., Moret, S., Truant, S. \& Conte, S.L. 2007. A survey on the presence of free glutamic acid in foodstuffs, with and without added monosodium glutamate. Food Chemistry 104: 1712-1717.

Raiten, D.J., Talbot, J.M. \& Fisher, K.D. 1995. Executive summary from the report: Analysis of adverse reactions to monosodium glutamate (MSG). Journal of Nutrition 125: 2892S-2906S.

Ryth-Rinder, M., Kerekes, N., Svensson, M. \& Hökfelt, T. 2001. Glutamate release from adult primary sensory neurons in culture is modulated by growth factors. Regulatory Peptides 102: 69-79.

Saad, B., Bari, M.F., Saleh, M.I., Ahmad, K. \& Talib, M.K.M. 2005. Simultaneous determination of preservatives (benzoic acid, sorbic acid, methylparaben and propylparaben) in foodstuffs using high-performance liquid chromatography. Journal of Chromatography A 1073: 393-397.

Stone, D.L., Smith, D.K. \& Whitwood, A.C. 2004. Copper amino-acid complexes-towards encapsulated metal centres. Polyhedron 23: 1709-1717.

Upadhyay, S., Ohgami, N., Kusakabe, H., Mizuno, H., Arima, J., Tamura, T., Inagaki, K. \& Suzuki, H. 2006. Performance characterization of recombinant L-glutamate oxidase in a micro GOT/GPT sensing system. Sensors and Actuators B 119: $570-576$ 
Yu, H., Ma, Z. \& Wu, Z. 2015. Immobilization of Ni-Pd/coreshell nanoparticles through thermal polymerization of acrylamide on glassy carbon electrode for highly stable and sensitive glutamate detection. Analytica Chimica Acta 896: 137-142.

\section{Noor Zuhartini Md Muslim*}

School of Health Sciences, Health Campus

Universiti Sains Malaysia

16150 Kubang Kerian, Kelantan Darul Naim

Malaysia

Musa Ahmad

Faculty of Science \& Technology

Universiti Sains Islam Malaysia

71800 Bandar Baru Nilai, Negeri Sembilan Darul Khusus

Malaysia
Lee Yook Heng

School of Chemical Sciences and Food Technology

Faculty of Science \& Technology

Universiti Kebangsaan Malaysia

43600 UKM Bangi, Selangor Darul Ehsan

Malaysia

Bahruddin Saad

School of Chemical Sciences

Universiti Sains Malaysia

11800 Pulau Pinang

Malaysia

*Corresponding author; email: zuhartini@usm.my

Received: 10 August 2017

Accepted: 25 October 2017 
